\title{
An Agenda for The Incheon Free Economic Zone: Developing Quad Ports and Quad Parks*
}

\begin{abstract}
Il-Soo Jun**
The Korean government designated three districts in the Incheon Metropolitan City as the first "Free Economic Zone" in August 2003. This paper discusses recent developments of and challenges to the Incheon FEZ, and proposes future tasks to accomplish Korea's goal to be a business and logistics hub in Northeast Asia. The master plan of the Incheon FEZ encompasses all elements of "Quad Ports and Quad Parks" in major development projects in three districts. Developing "Quad Ports and Quad Parks" in the newly introduced Incheon FEZ is expected to take on critical significance in the next decades by completely transforming the Korean economy and society. However, the success of the Incheon FEZ relies on massive reforms, which requires major and fundamental changes in both mindsets and strategies. First, the Korean government must develop its full potential by maximizing the strengths of the Capital Region. Second, the Incheon International Airport must be a principal driver of economic growth by improving accessibility to regional and global markets. Third, the New Incheon port should be developed in time for the Incheon FEZ to maximize its potential.
\end{abstract}

\section{INTRODUCTION}

The business environment in Northeast Asia is expected to undergo greater change in a next decade than it did in a last century. In particular, as China has successfully transformed itself into a global center of production and sourcing, most global firms are searching for opportunities to trade with and/or invest in China. These changes will precipitate a radical shift in the business operations of global firms in Northeast Asia in the 21st century. As global firms increase investment in this region to exploit opportunities, they need sophisticated economic and social systems to effectively support their production, trade and logistical activities. In this context, improving the efficiency of a country's business infrastructure and logistical services is of vital importance in attracting foreign capital, industry and commerce.

If Korea wants to become a business and logistical hub in Northeast Asia, it is true that the Korean peninsula has to be completely open and its business operations liberalized. We have witnessed, however, the strong opposition by labor unions and other interest groups against allowing various benefits and incentives to foreign investment even in the small areas of Free Economic Zones (FEZ).

* This work was supported by the Korea Science and Engineering Foundation(KOSEF) through the Northeast Asia e-Logistics Research Center at University of Incheon.

** Professor, Dean, Graduate School of Logistics Studies for Northeast Asia, The University of Incheon, Incheon, Korea 
So making the Koran peninsula completely open and liberalized will require substantial time and effort. Already, Korea is a late mover in the race for a regional business and logistical hub compared with competing cities such as Singapore, Hong Kong, and Shanghai and the Beijing-Tianjin corridor. In this connection, Korea does not have much time left or to make trials and errors. The window of opportunity for Korea is considered to be less than five years. The solution is to prepare an adequate development plan and strategy to achieve the goal, and constantly strive for differentiation. In this regard, there is a need to adopt a progressive development strategy, as was done in the Netherlands which gave the first priority to the region with international competitiveness, and then developed other parts subsequently.

To cope with this changing environment, the Korean government designated three districts covering 209 square kilometers in Incheon Metropolitan City as the first "Free Economic Zone" in Korea on August 6, 2003.' See Figure 1. This plan is a part of the Korean government's strategy of developing the nation into a business hub of Northeast Asia, which is pivotal in reaching the goal of national per capita income of US $\$ 20,000$. Much of the plan reflects Korea's ongoing endeavor to fully integrate itself into the global economy, upgrade its business environment and streamline government bureaucracy through a massive overhaul of laws and regulations. The development plan is scheduled to take place in two phases: the first is set for 2008 and the second for 2020 .

Although the Incheon FEZ is considered to be a key to building a foundation for a business and logistics hub in Northeast Asia, such a goal can not be achieved overnight. Becoming a business and logistics hub requires the well-planning and well-execution of a detailed strategy. Substantial efforts should be devoted to catching up with the early movers. Such strategy and efforts will determine the success or failure for the Incheon FEZ.

This paper discusses recent developments of and challenges to the Incheon FEZ, and proposes future tasks to accomplish Korea' s goal to be a business and logistics hub in Northeast Asia.

Figure 1. Incheon Free Economic Zone

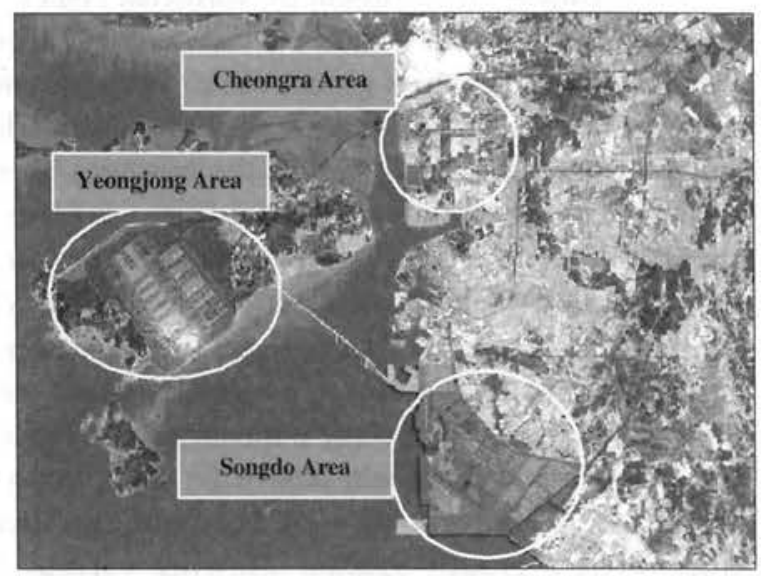

1 On November 14, 2002, the Korean government enacted The Act on Free Economic Zones in areas near international ports and airports, where international rules override local customs and, on the other hand, international tenets of law, order and common sense apply. The FEZ Services, an independent administrative support was inaugurated on October 15, 2003, to ensure that the zones will be transformed into territories that meet international standards. In October 2003, Busan and Gwangyang areas were also designated as Free Economic Zones. 


\section{DEVELOPMENT PLANS FOR INCHEON}

\section{Strategy for a Business Hub in Northeast Asia}

Traditional location criteria have emphasized cost-based variables such as input factor cost and transportation cost. Nowadays, however, social and institutional characteristics are given a great deal more weight in selecting the location of foreign direct investment (Brush et al., 1999).

A meta-analysis of the relationship between the determinants of FDI and Korea's competitiveness has been done to find out strengths of factors attracting business to and repelling business from Korea. As Figure 2 shows, although transportation infrastructure, a flexible labor system, efficient logistics services, a multilingual and productive workforce, and land related regulations are important determinants of foreign investment, they are identified as major barriers to FDI in Korea. International business and living environment and financial services are also listed as factors of weak competitiveness, even if they are relatively unimportant determinants. Information and Telecommunications infrastructure is a merit in attracting FDI and Korea' s competitiveness has been ranked high as we expect.

A combination of negative factors has contributed to Korea's falling behind Singapore, Hong Kong and major Chinese cities in terms of competitiveness. The Incheon FEZ has been developed in order to overcome the negative factors that discourage FDI in Korea.

Figure 2. Matrix of determinants of FDI and competitiveness position of business environment in Korea

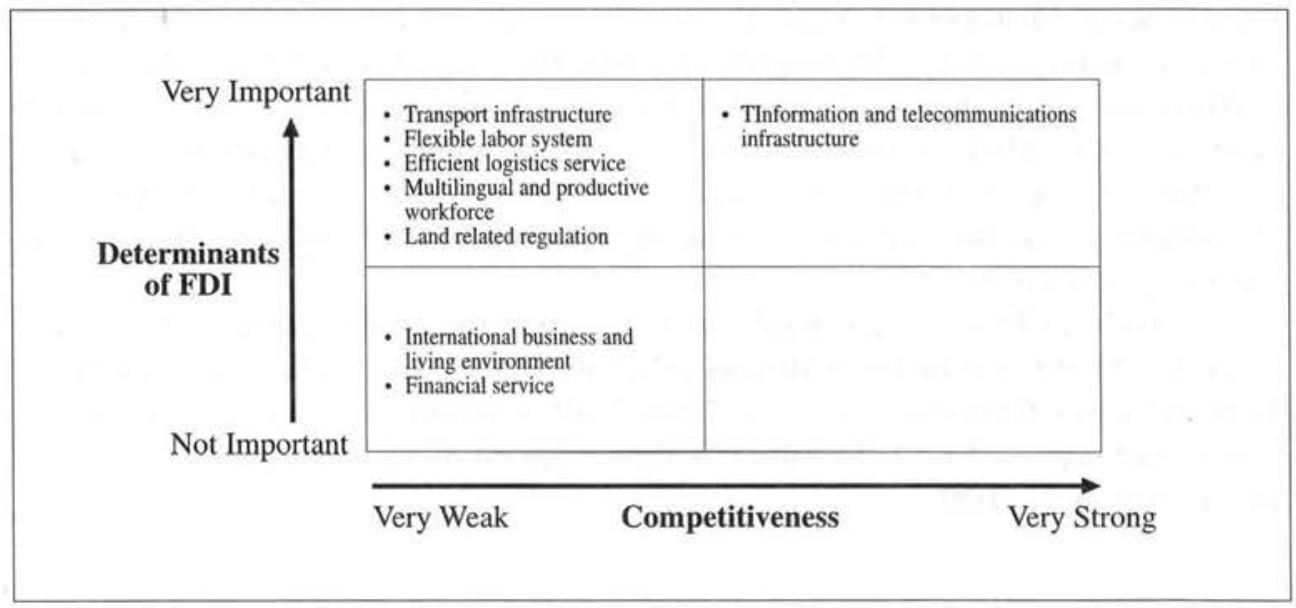

The FEZ will exempt foreign investors from income and corporate taxes for the first three years of business operations, while in the following two years, they will be entitled to a 50 percent deduction from the normal tax rate. They will also be exempted from tariffs on imports. 
For efficiency in conducting business, administrative services as well as all official documents will be provided in English. Foreign businesses in the FEZ will be relatively free from certain government regulations, such as the restriction on the facility location in the Capital Region. In addition to such incentives to attract foreign investment, the government plans to create an environment in which the residents can enjoy an international standard of quality of living from education to health care services. $^{2}$

Incheon is progressing toward becoming a gateway to the logistics and business hub in Northeast Asia because "its location at the heart of Northeast Asia is ideal for regional business" as reported in many economic geography studies. A population of about 2.6 million lives in an area of 980 square kilometers and 7,410 companies are engaged in business at present. The Incheon International Airport has made Incheon a big player on the international stage. It is growing into a hub of aviation and maritime transportation by connecting Northeast Asia, Europe, and the North American continent.

There are several reasons that make the "Incheon Free Economic Zone" special. First, Incheon, situated across the Yellow Sea from the Mainland China, possesses the ideal centrality in the major international air routes. Two billion people or 25 percent of the world population reside within a 3.5 hour flight from Incheon. Incheon International Airport has a lot going for a major airline hub. It is well-situated on major trade lanes. Geographically, it is two hours shorter to fly from Sydney, Australia, to London via

Incheon than via Singapore. It will be linked to China and Russia and further to Europe through the Trans-Siberian Railway and intercontinental highways in the future. Secondly, it has a perfect web of transportation, connecting Incheon and the Greater Seoul Metropolitan Area. As a result, foreign companies can make the most of the workforce in the Metropolitan Area, the largest and best in the nation. Furthermore, large industrial complexes in the vicinity of the zones will generate synergy effects. Marked synergistic effects owing to improved transportation systems together with a clustering of business, education, research, leisure and other socio/techno-economic activities can facilitate increased trade and economic growth within a given region.

The Incheon FEZ is expected to make a significant contribution to the Korean economy (MOFE and Incheon Metropolitan City, 2003): the Central Government and Incheon Metropolitan City will invest US\$12 billion in infrastructure projects; private and foreign capital of US\$155 billion will be invested in business, logistics, tourism, and residences by 2020 .

2 Part of the plan covers establishing branches of foreign schools, including post-secondary institutions. According to the most recent report, negotiations are currently underway to bring in such international schools. In the area of healthcare, the govemment hopes to establish branches of such world-renowned medical institutions. Adding to the high living standards will be the transportation infrastructure allowing for efficient travel not only to and from and within the special zone but also between this area and other parts of the country such as Seoul. Furthermore, international residents will be able to spend their leisure time in pleasant recreational areas spread throughout the region. According to the plan, more than 60 percent of the economic zone will be allocated for parks, green areas and recreational facilities. 
By then total new production will reach US $\$ 260$ billion and the value-added of the Incheon FEZ is expected to be around US\$106 billion. This will help to support at least 4.8 million jobs, and is expected to attract over US\$27.6 billion of FDI and two million tourists annually.If Incheon truly wants to become a logistics and business hub of Northeast Asia, it is essential to adopt a strategy developing Incheon to full potential. In particular, in order to strengthen the competitiveness of the FEZ, there is an urgent need to integrate Incheon International Airport with the Incheon Port, Yeongjong area, the Cheongra reclaimed area and the Songdo area by forming Quad Ports (airport, seaport, teleport, and leisure port) and Quad Parks (business park, distribution park, industrial park, and research park). ${ }^{3}$ See Table 1 . Nevertheless, the Incheon FEZ can not operate on its own. It is also desirable to integrate the Incheon FEZ with contiguous regions such as Shiheung City, Ansan City, Kimpo City and Pyungtaek City to develop them into free trade and logistics corridors. Shanghai alone is bigger than all these cities together. ${ }^{4}$

Table 1. Elements of Quad Ports and Quad Parks

\begin{tabular}{l|l||l|l}
\hline \multicolumn{2}{l||}{ Quad Ports } & Quad Parks \\
\hline \hline Airport & $\begin{array}{l}\text { Incheon International } \\
\text { Airport(Yeongjongdo) }\end{array}$ & Logistics Park & $\begin{array}{l}\text { Incheon International } \\
\text { Airport } \\
\text { Yeongjongdo } \\
\text { Existing Port area } \\
\text { Songdo }\end{array}$ \\
& & & $\begin{array}{l}\text { Songdo } \\
\text { Cheongra }\end{array}$ \\
\hline Seaport & $\begin{array}{l}\text { Existing Incheon Port } \\
\text { North Port } \\
\text { Technoport } \\
\text { (Teleport) }\end{array}$ & $\begin{array}{l}\text { South Port } \\
\text { Sewgdo Incheon Port(Songdo) }\end{array}$ & R\&D Park \\
& (Research Park) & \\
\hline Leisureport & $\begin{array}{l}\text { Yeongyu/Mueui } \\
\text { Existing port area }\end{array}$ & Bndustrial Park & $\begin{array}{l}\text { Existing parks } \\
\text { Yeongjongdo } \\
\text { Cheongra }\end{array}$ \\
& Cheongra & $\begin{array}{l}\text { Songdo } \\
\text { Yeongjongdo } \\
\text { Cheongra }\end{array}$ \\
\hline
\end{tabular}

${ }^{3}$ In Ocean Korea 21, the Ministry of Maritime Affairs and Fisheries developed a new concept, a so-called Pentaport, which comprises seaport, airport, business port, technoport, and leisure port. This concept is one step ahead of the traditional Triport (seaport, airport, and teleport) concept. However, even the pentaport concept does not cover the whole spectrum of activities envisaged in the future of the Incheon FEZ. Only the "Quad Ports and Quad Parks" concepts are able to capture all the necessary elements to achieve the goal of the Incheon FEZ.

4 Shanghai alone equals 54 percent of the Korea's Capital Region in terms of land size and 60 percent in terms of population. 


\section{Major Development Projects}

The master plan of Incheon FEZ encompasses all elements of Quad Ports and Quad Parks as identified in major development projects in three districts such as:

- Songdo Intelligent City as knowledge-based industry, R\&D and international business centers;

- Yeongjong area as a global logistics center and tourism and leisure areas; and

- Cheongra reclaimed area as an international finance center, and tourism and leisure complexes.

\section{The Songdo Area}

Songdo area is the reclaimed land of 53 square kilometers located in the southwest of Incheon. Incheon Metropolitan City holds land ownership and is a major developer.

The projected population is 95,400 households with 243,300 people. The regional headquarters of multinational corporations and centers of international business will be invited to locate in the Songdo New Town, which will feature the networking and clustering of advanced knowledge-based industries, notably Information Technology (IT), Bio-Technology (BT) and Nano-Technology (NT). By 2010, the entire New Town area will be connected by an advanced computer network system as a state-ofthe-art Information and Digital city. Already, significant progress has been made in attracting FDI to the New Town. The International Business Center (IBC) zone will be developed by 2013 by the Gale Company and the POSCO E\&C consortium 5 . The High-tech Bio Complex will invite Bio-engineering research institutes and businesses. In February 2002, four companies including VaxGen ${ }^{6}$ of the U.S., Korea Tobacco \& Ginseng Corporation, and two other companies agreed to set up a joint venture, Celtrion. Songdo New Port and a new maritime logistics complex will be developed in the south of Songdo area to handle the increasing volume of container cargo to and from China. With this development, the Port of Incheon will play the role of a major hub port in the Yellow Sea region, particularly by establishing efficient short sea shipping routes in the region. Vast areas contiguous to the New Port will be developed for distribution facilities, value-added logistics centers, and supporting business activities.

5 They will invest US $\$ 12.7$ billion and Incheon City will invest US $\$ 0.8$ billion, respectively. The facilities in the IBC zone include international business complex, department stores, shopping malls, convention centers, golf courses, office buildings, hotels, medical facilities for foreigners, international schools, and residential complexes.

${ }^{6}$ In 2001 the VaxGen Company from the United States has contracted to invest US\$150 million in producing new biotechnology products. 


\section{The Yeongjong Area}

This area of 138 square kilometers includes the Incheon International Airport (IIA), and the Yeungjong, Yongyu, and Mueui islands. The projected population is 54,930 households with 142,500 people.

Development policy is to expand Incheon International Airport as the Northeast Asian hub airport and to develop the Incheon International Airport Free Zone, the Industrial Logistics Complex and the International Tourist Complex. According to this policy, the Yeongjong area will have diverse facilities such as airport, leisure port, logistics park, industrial park and business park.

The Incheon International Airport handled 126,094 planes, 21 million passengers and 2 million tons of cargo in 2002. Incheon has enough land nearby to allow it to quadruple its capacity by 2020 . Upon completion of the final phase of development by 2020 , the IIA is expected to handle 530,000 planes, 100 million passengers and 7 million tons of cargo annually, which is greater than any air port's current load in Northeast Asia. The Incheon International Airport will become a prime example of facilities designed to serve global firms' need for rapid transportation to move their products and services.

The Incheon Airport Free Zone is located east of the cargo terminal. The facilities of this zone will be supported by warehouses, distribution centers, aircraft parts centers, etc. The project cost of this zone is US\$ 86.9 million. The site was designated as a Customs-Free Zone, the first of its kind in Korea, in February 2002. The Customs-Free Zone is expected to start operation from April 2005. The Industrial Airport Logistics complex of 2.07 square kilometers will be located at the southeast area of Incheon Airport Free Zone and Northeast of New Airport Town. By 2006, this complex will be developed into high-value manufacturing and air logistics centers linked with the IIA and Incheon Airport Free Zone.

Both the Airport Free Zone and the Industrial Airport Logistics complex will be principal drivers of economic growth as high-tech manufacturers and global logistics service providers concentrate their production/value-added logistics facilities in them to take advantage of access they offer to global and Chinese markets.

The leisure port project is also envisaged to develop tourism resources in the islands of Yongyu and Mueui, which are located southwest of the Incheon International Airport. This project is to develop these islands as a world-class resort by 2016 . The marine resort will host marina facilities and other types of marine recreation amenities on a scale hitherto unparalleled in Korea.

\section{The Cheongra Area}

The Cheongra area is slated to be a stronghold of international business and finance, the floral complex, and global entertainment. This area of 18 square kilometers is at the northwest reclamation site in Incheon City. The projected population is 29,350 households with 90,000 residents. 
The development policy of this area is to build an international business center and a residential complex as well as leisure and sports facilities such as theme parks and golf courses. Key elements of the IBC are world-class financial institutions, offshore financial centers, financial consulting companies, banks, exhibition centers, and regional headquarters of global firms. A High-tech Floral Complex of 1.88 square kilometers will be developed during the period of 2004-2008.

The development policy is to house world-class large flower farms, which are expected to offer refreshing experiences to foreigners, visitors and residents, and to attract a hi-tech complex of genetic and environmental engineering.

\section{The Road Ahead for the Incheon Free Economic Zone}

Although a wide range of issues could be dealt with for enhancing competitiveness of the Incheon FEZ, the challenges to be discussed in this section will be restricted to two key areas: enhancing the function of the Capital Region and developing Incheon's ports and airport into logistics and industrial clusters.

\section{Enhancing the Capital Region}

Recent changes in the technologies of production, transportation and communications have radically altered the economic spaces in which economic activity is conducted. As a consequence of these structural changes, responsibility for enhancing the competitiveness of economic entities has been transferred from the "nation" to "sub-nation entities" (cities or economic regions). According to Porter's diamond of determinants of competitive advantage, local regions have a key influence on two of the four determinants: "factor conditions" and "related and supporting industries." Porter makes this quite explicit: Internationally successful industries and clusters frequently concentrate in a city or region, and the bases for advantage are often intensely local(Porter, 1990).

Consequently, the nation is not considered to be valid focus of competitiveness nowadays. That is, since competition takes place at the city or regional level, analysis of national competitiveness between China and Korea is no longer valid. Rather, the more important competition takes place between cities or economic regions: Shanghai (or Beijing-Tianjin) vs. the Capital Region of Korea. In this view, there is a need to change fundamentally the policy paradigm for the Capital Region in the Korean government so as to enhance its competitiveness. The Capital Region is able to offer necessary elements for the Incheon FEZ to maximize its potential, by facilitating access to factors of production as well as providing proximity to important markets/suppliers and key customers/facilities.

The KRIHS survey (2000) reveals that 70 percent of foreign investment is concentrated in the Capital Region in terms of the number of companies. Ninety percent of foreign global firms already in Korea prefer to expand their facilities at existing sites rather than in another locale. 
As such, more than sixty percent of subsequent investment is expected to take place in the Capital region, in spite of regulations that make it less beneficial to invest in the Capital Region over other parts of Korea. All told, foreign global firms prefer to locate themselves in the Capital Region. Another study (Kim, 1997) identifies major barriers to foreign investment, by selected sector, as shown in Table 2. For the manufacturing and service sectors, land-related regulations (including plant location, construction and administrative regulations) are the biggest barrier. An insufficient logistics infrastructure is also listed as a significant obstacle.

Table 2. Major Barriers against Foreign Investment by Sector

\begin{tabular}{|c|c|c|c|c|c|}
\hline \multirow{2}{*}{\multicolumn{2}{|c|}{ Sector }} & \multicolumn{4}{|l|}{ Barriers } \\
\hline & & \multirow{2}{*}{$\begin{array}{l}\text { 1st } \\
\text { Land related } \\
\text { regulation }\end{array}$} & \multirow{2}{*}{$\begin{array}{l}\text { 2nd } \\
\text { Skilled labor }\end{array}$} & \multirow{2}{*}{\begin{tabular}{l}
\multicolumn{1}{c}{ 3rd } \\
Logistics \\
infrastructure
\end{tabular}} & \multirow{2}{*}{$\begin{array}{l}\text { 4th } \\
\text { Intellectual } \\
\text { property } \\
\text { protection }\end{array}$} \\
\hline Manufactruing & Machinery & & & & \\
\hline & $\begin{array}{l}\text { Semi- } \\
\text { conductor } \\
\text { Equipment }\end{array}$ & $\begin{array}{l}\text { Labor } \\
\text { system }\end{array}$ & $\begin{array}{l}\text { Logistics } \\
\text { infrastructure }\end{array}$ & $\begin{array}{l}\text { Land related } \\
\text { regulation }\end{array}$ & Tax system \\
\hline & $\begin{array}{l}\text { Electric/ } \\
\text { Electronic }\end{array}$ & $\begin{array}{l}\text { Land related } \\
\text { regulation }\end{array}$ & $\begin{array}{l}\text { Labor } \\
\text { system }\end{array}$ & Infrastructure & Customs \\
\hline Services & Distribution & $\begin{array}{l}\text { Land related } \\
\text { regulation }\end{array}$ & Customs & $\begin{array}{l}\text { Market } \\
\text { access }\end{array}$ & $\begin{array}{l}\text { Logistics } \\
\text { infrastructure }\end{array}$ \\
\hline
\end{tabular}

Source: Kim(1997)

Those who advocate regulating the Capital Region assert that such regulations help to control excessive concentration of industrial activity and contribute to increased development in other parts of the country. Though it is true that fairness may be an important factor in evaluating the system, there is no clear standard as to what constitutes fairness. ${ }^{7}$ The Korean government has severely restricted the placement of logistics ports and logistics centers as well as higher education facilities in the Capital Region, in an attempt to prevent unbalanced national development. But the social costs of such policy were enormous. Ironically, the statistics show that there has been an increase in the over-concentration of business activity. Likewise, a review of cases from the world clearly indicates that government policy that attempts to control or suppress a Capital Region has not been successful in any country. On the contrary, such policy tends to lower industrial efficiency and distort location.

\footnotetext{
7 According to Posner, economic efficiency is an adequate standard for determining faimess. He reasons that a system that achieves potential Pareto superiority simultaneously maximizes overall welfare, thus bringing benefits to nearly everyone. Therefore, there is a need for a mechanism by which the main beneficiaries of liberalized Capital Region restrictions can return some of the benefits in the form of financial support to local governments or industry. Then, the entire country will enjoy a significant net gain.
} 
The capital region policy of other countries have all followed a similar path of reform. For example, in order to control the growth of their capital cities, the U.K. and France used to control new construction and factory expansion, institute policies that allocate manufacturing industries more evenly, regulate commercial building construction, and locate public institutions in local regions. However, these efforts were not successful.

Beginning in the mid-1980s, partly in preparation for the European Union, the focus of such policies shifted, with greater emphasis placed on strengthening national competitiveness by making the capital regions into more globally competitive cities.

In fact, in the London metropolitan area, there are no longer any regulations restricting business activities in the capital region. In France as well, officials realized that the national policy of preventing overcrowding in the capital region had the adverse effect of weakening the global competitiveness of its industries. Thus, France changed its policies so as to strengthen functions related to central operations and advanced business functions.

Even the Netherlands was at one time concerned about the unbalanced development of its local economies. However, as competition between regions and cities continued to grow, the government decided to focus on enhancing the competitiveness of the Randstad region containing four largest cities of the country as well as the two main-ports: Rotterdam Port and Amsterdam Schiphol Airport. ${ }^{8}$ The national government provided its full support to the effort in the hopes of contributing to the development of the national economy(Harding, 1994).

Whereas, the Korean government is still placing restrictions on developing ports and logistics centers in the Capital Region'. The North Incheon Port project, which was supposed to build a port capable of handling cargo directly from factories in the adjacent region, is a case in point. The project was initiated in the early 1990s, but to this day therehas been little in progress. Because logistics centers are the source of high value-added activity, it is important that they be located according to market principles.

For the Incheon FEZ to maximize its potential, strengthening the global capabilities and competitiveness of the Capital Region is of the utmost urgency. The Capital Region in Korea is relatively rich in software infrastructure, including logistics services and professionals who can handle foreign languages and the cultural demands of foreign firms.

8 In the 1* National Policy Document on Spatial Planning (NPDSP) in the Netherlands (1960), the main emphasis

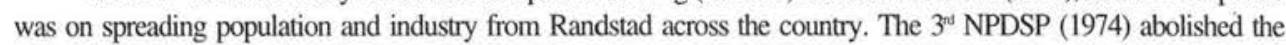
dispersal policy of population and industry. A major shift of policy occurred in the $1990 \mathrm{~s}$. In the current policy of the $4^{\text {th }}$ NPDSP (1990), the central theme is that spatial planning should support Randstad's competitiveness in an international perspective. For details, see KRIHS and GEM Consultants (1998).

${ }^{9}$ Particular mention should also be made regarding the spatial planning policy of the Netherlands. Even in the $1^{\text {s }}$ NPDSP which controlled the growth of Randstad region, the Netherlands government made an exception to the Port of Rotterdam to support its economic contribution to the national economy. 
So, the Capital Region location regulations regarding industry, logistics and education facilities make it impossible to make use of the various international functions of the Capital Region, thus making it more difficult to induce foreign investment. In the end, location regulations in the Capital Region will seriously hinder Korea's national competitiveness, without bringing about more balanced national economic development. ${ }^{10}$

\section{Developing Ports and Airports into Logistics Centers}

Relative to Europe and North America, the development of logistics systems in Northeast Asia has not kept pace with the rapid growth in today's logistics demand. To appropriately respond to these environmental changes, certain strategies must be implemented. In particular, it is important to build logistics centers where efficient, cost-effective logistics services add a great deal of value to the products, thereby supporting economic development of the regional and national economy.

Although logistics centers have not been considered in the traditional internationalization model, they certainly should be considered an important step in the overall internationalization process. When analyzing the amount of foreign direct investment in the 1960-1993 period, Jagersma (1994) concluded that most regional distribution centres could be placed between the phases 'location of trade offices' and 'location of production centres' in the development model. He also found that on average one European Logistics Center (ELC) resulted in 3 extra indirect foreign investment projects in the Netherlands (of more than US\$ 5 million). This result implies that logistics centers in Incheon FEZ will help host the Korean economy's overall internationalization patterns and support the strategies of global companies.

ELCs are often forerunners for the establishment of other international activities in the Netherlands, such as head offices, shared service centers and call centers. Figure 3 cited from the survey by the Holland International Distribution Council (2001) gives an insight into the spin-offs from ELC developments in terms of other international business functions in the Netherlands.

Many of the foreign firms that had established an ELC in a port/airport of the Netherlands later decided to move their European headquarters, customer call centres, and training and R\&D centers to the Netherlands. This has been the case with 47 percent of the ELCs set up in the Netherlands. The reverse is far less frequent?only 17 percent of ELCs were created following the establishment of other international activities by the companies concerned.

This is one of the important reasons why the logistics centers have been a major contributor to the high economic growth rate of the Netherlands amidst the intense competitiveness of the European market.

10. If Korean govemment truly wants to prevent overcrowding in the metropolitan area and achieve more balanced economic development, this can be best achieved not through restrictive policies and regulations, but rather through the use of a detailed and well-planned incentive scheme as well as the dispersal of the overly concentrated central government's power. 
Figure 3. Developments in international activities ELC's

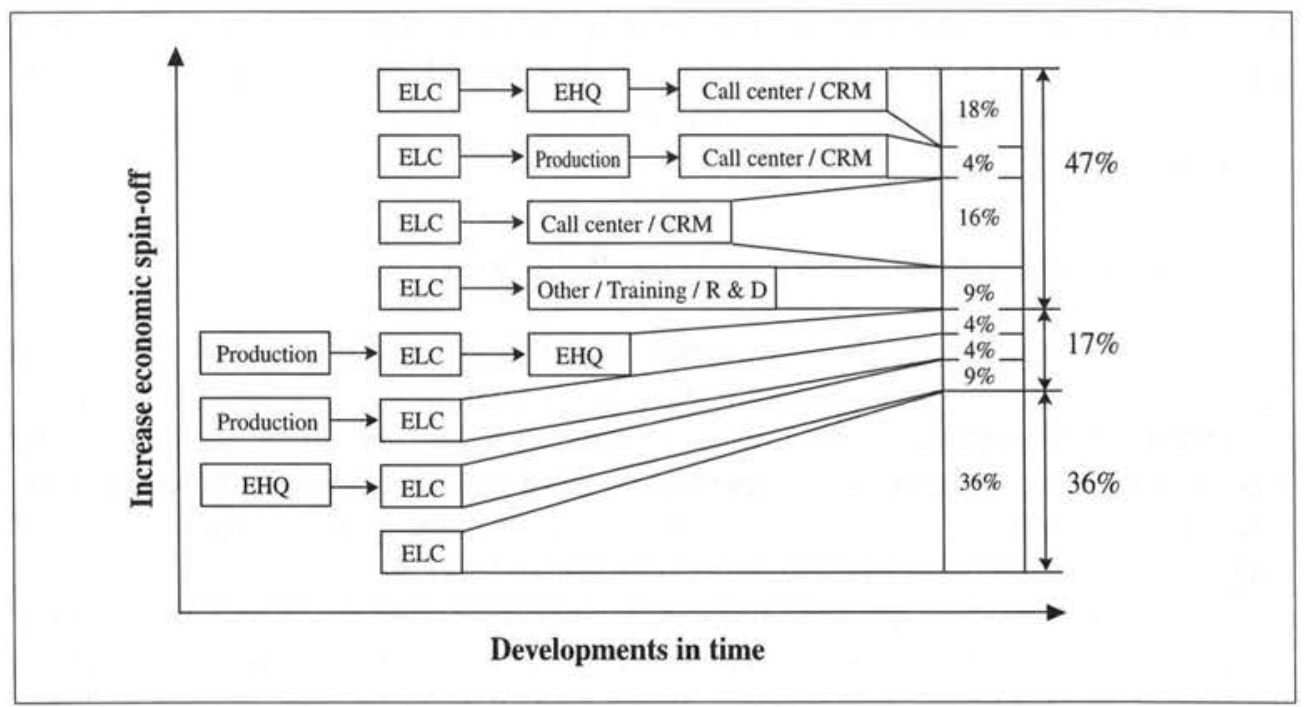

Source: HIDC (2001)

The Incheon FEZ is expected to gain a sustainable competitive advantage by attracting greater value-added logistics activities of global firms while bringing down their operating costs. The benefits of having logistics centers for providing valueadded logistics services are evident in the examples of the Netherlands, Singapore, Hong Kong, Taiwan, Dubai and Panama. In order to attract global logistics activities within their respective regions, these countries have consistently expanded their logistics facilities such as ports and airports. Using such facilities as a base, they have actively established free trade zones as part of their efforts to consolidate and centralize logistics management. These countries, each of which is a major regional logistics center, have become favorite business locations for global firms.

In this vein, the Incheon FEZ must put forth greater effort to develop its free logistics and industrial complexes in port and airport areas in addition to expanding its port and airport facilities. In this case, logistics centers in the areas around Incheon Airport and Incheon port should be able to provide both a logistics promotion function and a value-added logistics (VAL) function."

"The main VAL functions are:

- Receiving goods, breaking shipments, preparing for shipment, returning empty packaging;

- Simple storage, distribution, order picking;

- Localizing and customizing, adding parts and manuals;

- Assembly, repair, reverse logistics;

- Quality control, testing of products;

- Installing and instruction;

- Product training on customer' s premises. 


\section{(1) Airport: from transportation node to economic growth pole}

According to the OECD, almost 40 percent of world trade in goods by value is now carried by air. Consequently international business, logistics and manufacturing centers clustering around airports. The success of an airport depends a great deal on how successful it is at attracting global, regional and local centers for various types of high-valued activities. These high value-added activities in airport areas play a key role in determining lasting economic growth of an airport and its hinterland. A comprehensive empirical study by Button and Stough (1998) identifies the impact of hub airport on an area's high-tech job growth. Their analysis across all 321 U.S. metropolitan statistical areas shows that the causal link between job growth and degree of airport services flows from air transportation input to creation of employment and not the other way around.

Global firms have recognized that increased global trade has brought with it the need to efficiently transport vast volumes of unfinished merchandise over long distances in a very short period of time. Since time of service is seen as critical, hightech manufacturers and global logistics service providers concentrate their facilities near international gateway airports to take advantage of time-cost access to global markets.

A recent survey shows that more than 80 percent of high-tech manufacturers prefer to locate their facilities near major airports. ${ }^{12}$ (O' Brien, 2001) As such, locations near airports have become increasingly agglomerations of industrial and commercial development. Successful examples of these clusters around the world $\operatorname{are}^{13}$ :

- In the 26-mile commercial corridor linking Washington, D.C.'s Reagan (National) and Dulles Airports, employment grew from 50,000 in 1970 to 600,000 in 1996, representing a twelve-fold increase compared to an overall U.S. employment growth of 59 percent during the same period.

- The once-sleepy Memphis, Tennessee has been transformed into a center of international business by gaining competitive advantage through air logistics. ${ }^{14}$

\footnotetext{
${ }^{12}$ In addition to their growing attractiveness as sites for modern manufacturing and logistics industries, airports are becoming magnets for corporate headquarters and regional offices as well as for professional services, such as consulting, that require considerable employee long-distance travel. Airport accessibility is likewise a powerful draw to service-sector industries such as advertising, legal, data processing, accounting and auditing, and pubic relations that frequently send out professional staff to customers by air. The same applies to high-tech industries whose supply chain management relies extensively on air shipments and where employees have a 60 percent higher air travel propensity than workers in general.

${ }_{13}$ The list that follows draws on a variety of sources but particularly see Erie et al. (1999), Kasarda (1999), and Nasser (2003).

${ }^{14}$ Memphis International Airport is the world's largest cargo airport due to the presence of FedEx's World Headquarters and Superhub.
} 
Since FedEx established its hub in 1974, Memphis has attracted billions of dollars in investment in manufacturing and logistics facilities in the vicinity of airport. Since 1980, more than 130 foreign-owned firms from 22 countries employing 17,250 workers have been drawn to Memphis. Since 1991, more than 20 major U.S. companies have invested in and established new manufacturing and logistics centers near the airport. Nearly all these companies pointed to the FedEx hub as a key attraction.

- The number of companies within the dynamic Las Colinas area just to the east of Dallas-Fort Worth International Airport (DFW) has grown to more than two thousand. The economic impact of the DFW to the north Texas area is estimated at US $\$ 8.4$ billion, with US $\$ 4$ billion generated directly by DFW airport activities.

- Alliance Industrial Airport at Fort Worth, Texas has landed more than 50 companies during the $1990 \mathrm{~s}$, generating US $\$ 3.6$ billion in new investment. The Alliance complex alone has contributed more than US $\$ 2$ billion in new area business developments and has led the surrounding area in housing starts and new home sales. Alliance is currently developing 1,277 acres as an Advanced Technology Center US $\$ 1.3$ billion computer chip manufacturing facility with space for nearly six million square feet of planned buildings at the Center.

- Atlanta, Georgia attracted 813 foreign firms generating US\$33 billion in investment and 54,000 jobs in the 10 years following the introduction of international air service in 1975. An airport is attributed to be the most important factor in determining the location of an international business, especially an airport with direct international air service.

- The Rickenbacker International Airport in Columbus, Ohio, which used to be an army airbase, was successfully converted into a dedicated cargo airport, foreign trade zone, and industrial park. Since the early 1990s, Rickenbacker has attracted dozens of development projects with more than six million square feet of commercial space constructed and occupied by 1997.

- The International Intermodal Center at Huntsville International Airport, Alabama serves as an alternative southern gateway for shippers. Its continued expansion has contributed more than US\$1 billion in private sector investment and added another 15,000 manufacturing jobs in the area.

- Subic Bay Freeport in the Phillippines, is rapidly expanding around a former U.S. naval airbase converted to commercial use in 1993. Since FedEx announced in 1994 that it was locating its intra Asia-Pacific hub at Subic Bay, over 150 firms employing 50,000 workers have located there, generating more than US $\$ 2.5$ billion in investment ${ }^{15}$.

- By late 1997 , nearly 50,000 people were employed on the airport grounds at Amsterdam's Schiphol Airport, a 7.2 percent increase over the previous year. Schiphol airport alone accounts for 10 percent of the European air cargo market and 1.9 percent of Netherlands' GNP. It is forecast to generate 2.8 percent of Netherlands' GNP by 2015 (approximately US $\$ 14$ billion).

is In 1998, Acer completed and opened its largest PC assembly facility in the world, heavily utilizing air express for its supply chain management. 
Likewise, speed and agility have become so critical in the new economy of Korea. Currently, already more than one-third of the value of trading products of Korea is transported by air, and a percentage is continuously rising. The tremendous potential around Incheon International Airport and Yeongjong area will present a prime example of so-called "aerotropolis" phenomenon largely because of the accessibility it provides to regional and global markets.

(2) Port: from traditional cargo-handling services to value-added logistics services ${ }^{16}$

Although airfreight is quickly becoming the logistical backbone, most of the manufactured goods in international trade still travel by sea. Surveys of location determinants for global firms in the Netherlands and Singapore show that global firms prefer sites that have convenient access to both an airport and a seaport. This is because they have to use both an airport and a seaport to meet 100 percent of logistics needs. The Netherlands and Singapore have been successful in carrying out their role as regional hubs because they have well-developed airport and port infrastructures as well.

These days, the commercial success of a port could stem from a productivity advantage in traditional cargo-handling service, from value-added logistics service, or from a combination of the two. Productivity advantages come mainly from economies of scale and economies of scope, suggesting that the most productive ports will be those that are equipped to handle large cargo volumes and/or significantly reduce unit costs through efficient management. Shippers and carriers select individual ports not only based on their cargo handling service capabilities, but also the benefits they are capable of "delivering."

Unless a port can deliver benefits that are superior to those provided by its competitors in a functional aspect, port customers are likely to select ports based merely on price. This fact raises the question of how a port can achieve value differentiation.In the 1970 s, almost every port provided the same basic package of services to almost every customer. Nowadays, however, it is more difficult for ports to compete on the basis of cargo-handling service. There has been a convergence of technology within cargo-handling service categories. This means that though new technology may sometimes provide a window of opportunity for productivity improvement, in many cases that same technology is also available to competitors. It is no longer possible to compete effectively on the basis of basic, traditional functions. Thus, there is a need for ports to seek out new means of gaining a competitive edge.

The late 1980s saw the emergence of major changes. Customers began to ask ports to provide a greater variety of services. Providing value-added services is a powerful way for ports to build a sustainable competitive advantage. Shippers and port customers are becoming increasingly demanding. Customers now tend to look at value-added logistics services as an integral part of their supply chain.

\footnotetext{
${ }^{16}$ A large part of this section is adapted from Jun (2002).
} 
As a result, ports must attempt to satisfy these needs by offering differentiated services. This poses a particular challenge for port management.

Studies show that the most successful ports are those that not only have a productivity advantage in cargo-handling services, but that also offer value-added logistics services. Thus, there are several available options for ports to choose, as shown in the simple matrix in Figure 4.

Figure 4. Matrix of competitive advantage

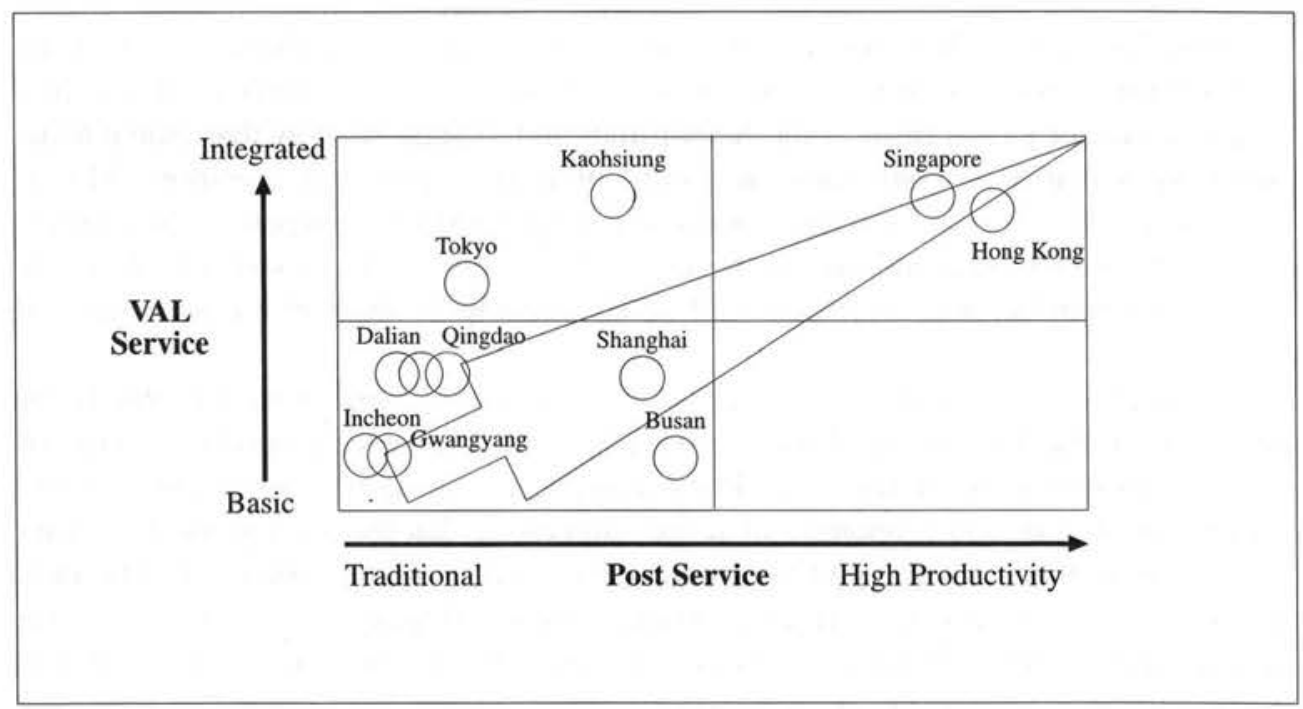

The ports such as Incheon and Gwangyang providing traditional services in the bottom left hand corner of the matrix are indistinguishable from their competitors. The only option for such ports is to move to the right side of the matrix, toward productivity-advantage leadership, or to move upwards, towards value-added logistics service leadership.

Meanwhile, we see the dominance of superior service leaders such as Singapore and Hong Kong that possess both a productivity advantage and a VAL advantage. In between traditional service ports and superior service ports are the leading-edge service ports such as Shanghai and Kaohsiung. These are the ports that are on their way to becoming superior service ports. A number of ports are responding to this trend by focusing on value-added logistics services as a means of gaining a competitive edge.

Incheon port could experience synergistic benefits from logistics centers to provide value-added services, since the logistics center can attract cargo that can be shipped through the port. There is a positive correlation between cargo flows at the logistics center and the number of ships calling at the port. In other words, the cargo attracts the ships, and the ships attract the cargo. 
Incheon Port will benefit by generating increased revenue and creating jobs from the increased flow of cargo through the logistics operation.

The ports of Rotterdam and Singapore have been phenomenally successful in attracting regional logistics centres and related economic activities into the port area. Likewise, Incheon port should provide a diverse range of value-added services that are highly integrated.

\section{(3) Major Tasks for Incheon Free Economic Zone}

The Netherlands and Singapore have become super-hubs for business and logistics activities in their respective regions by attracting a large number of global and regional logistics centers of foreign multinationals. They may not be superior to Germany and Bangkok in terms of geo-economically strategic position such as centrality and intermediacy. However, the former two have been far more successful than the latter two mainly because they have built up logistics capability in advance of need, and because of their business-friendly economic and societal environment. These successful examples present Incheon FEZ with a clear direction.

Incheon's targeted foreign global firms are expected to be European and North American firms that are using Korea as a gateway to the Chinese and Japanese markets for medium- and upper-grade products (components, semi-finished goods, and finished goods). To satisfy the growing requirement of these firms to ship products quickly to customers, there is an urgent need to speed up the development of the Incheon Free Trade Zone. To fulfill its mission, however, Incheon is finding itself faced with a new set of challenges.

First, there is a need for a systems-oriented approach for planning and developing logistics complexes in Incheon airport areas to meet the demands of shippers, airport service providers, and citizens. The salient feature of the existing land use plan at Yeongjong Island is that Incheon municipal government has not adequately understood the importance of sufficient land space for developing logistics centers. Consequently, there has been little consideration of the need to secure sufficient land space for the development of logistics and industrial activities in the process of planning and development of Yeongjong Island.

Since the shortage of land space will inevitably lead to the difficulty in building logistics and industrial clusters at most desirable sites, Incheon municipal government should place a high priority, in advance, on preventing the land space behind the airport from being used in random development or from being used without regard to the original airport and logistics-related functions. In this process, the Central Government, the Incheon municipal government and the Incheon International Airport Corporation should partner to conduct in-depth research in planning and developing the logistics and industrial clusters in airport areas. This research would prepare for future requirements, help avoid possible conflicts among all parties involved in the development, and promote integrated and rapid development. 
Second, since it is essential for airport and industrial/logistics centers to have easy access to inland transport and close inter-connection between them to perform their functions properly, providing or improving rail and local road access into industrial/logistics centers should be one of the highest items on the agenda in Incheon FEZ development strategies. ${ }^{17}$

Since industrial and logistics complexes should be selected for ease of access to inland transport, strong assistance by the Central Government will be necessary with regard to land, roads, railways, and energy. In particular, strong national and local governments' assistance is essential for timely completion of the $2^{\text {nd }}$ bridge connecting Yeongjong Island and Songdo New Town. Timely national budget outlay is also necessary to speed up infrastructure construction ahead of schedule, such as the Airport Railway. In addition, early construction of the $2^{\text {nd }}$ Outer Beltway and the $3^{\text {rd }}$ Seoul-Incheon Turnpike are also needed to accelerate the development progress of the Incheon FEZ.

Third, to function as a business and logistics hub of Northeast Asia, the Incheon FEZ has to enhance accessibility to the Northeast Asian market by providing efficient and cost-effective port facilities. Although container traffic between China and Korea increases by leaps and bounds every year and about 40 percent of total containers handled in Korean ports is to or from the Capital Region, which is the major industrial and population concentration in Korea, the existing Incheon port handled only 6.5 percent of total container cargoes in 2002 . However, owing to the restrictive policy on developing ports and logistics facilities in the Capital Region, the handling capacity in Incheon port is unable to meet the ever-increasing demand. Furthermore, it should be noted that Incheon's logistics and port facilities fall far behind other competing ports in Northeast Asia in terms not only of quantity but also of quality.

Fourth, efficient management of the Incheon FEZ Service is essential to catch up with rapid development in competing cities like Beijing-Tianjin, Shanghai and Hong Kong. It should be an agency operating in a business-like manner by reforming rigid bureaucracy and administrative practices.

To function properly, it should openly recruit experts and civilians with global mindset and expertise regardless of nationality and should form a mission-oriented task force to secure administrative flexibility sensitive to public demands.

Otherwise, it would be a "one-more-stop" service organization, not a "one-stop" service organization. A major task of the Incheon FEZ Service should be conducting investment promotion designed to attract FDI, which includes image-building and investment-generating activities and investment-facilitation services. Post-investment services are also important tasks.

Finally, to achieve its goal, the Incheon FEZ must concentrate not only on expanding the transport and logistics facilities, but also on raising the quality of the living environment including educational institutions, and medical services so that it attracts global firms and the world's leading human resources.

\footnotetext{
${ }^{17}$ In a similar case, to achieve an efficient, seamless transport and distribution system, the Integrated Transport Strategy of the Sydeny Ports Corporation makes it clear that land transport is of no less importance than adequate port facilities and services (Hayes, 2002).
} 
To meet the demand for the investment in these projects, however, an enormous amount of private and foreign capital is needed. Out of the US\$168 billion to be invested in the Incheon FEZ, central and local governments' support makes up no more than US $\$ 12$ billion. Therefore, abundant domestic liquidity including the commercial immovable fund, the national pension fund, Postal Service, insurance and the foreign exchange reserve should be utilized to facilitate project financing. Also, in expanding the base of project financing, a shift of focus should be made to financial and strategic investors from traditional construction companies. To fulfill the requirements of the Incheon FEZ, a law must be enacted for project financing investment firms. Its main contents should include: a comprehensive investment permit for infrastructure, medical care, commercial buildings and tourist facilities; exemption from corporation tax, acquisition tax, and registration tax for distributed income and investment assets; and easing the limit on potential investors including banks and insurers.

\section{CONCLUSIONS}

Developing "Quad Ports and Quad Parks" in the newly introduced Incheon FEZ is expected to take on critical significance in the next decades by completely transforming the Korean economy and society. However, the success of the Incheon FEZ relies on massive legal and regulatory reform which is facing difficulty in implementation in the increasingly pluralistic and noisily democratizing society, that is present-day Korea.

First of all, to achieve the aim of a logistics and business hub in Northeast Asia, the Korean government must follow market principles in developing its full potential by maximizing the strengths of the Capital Region. That is the only region at present which has the potential to have a marked synergic effect with the Incheon FEZ by facilitating access to factors of production as well as providing proximity to network nodes. Success or failure for the Incheon FEZ will depend on how effectively it attracts FDI. A striking feature of both existing firms and firms who intend to invest in Korea is that demand for high-tech manufacturing sites within the Capital Region is increasing more rapidly than ever, despite the negative externalities experienced in the region.

In this regard, policy regulations that disfavor the Capital Region in Korea should be re-evaluated in order to enhance the competitiveness of manufacturing and logistics industries and to more effectively induce foreign investment.

Global firms operating in Korea prefer to invest in well-planned industrial parks with well-developed logistics infrastructure. In order to attract foreign global firms, the provision of proper sites should be made to meet their requirements. As growing time-based competition makes high-tech manufacturers concentrate production facilities near well-served airports to take advantage of the links they offer to regional as well as global markets, Incheon International Airport must be a principal driver of economic growth. The message from worldwide experience and research studies is clear. 
The central government, the Incheon municipal government and the Incheon International Airport Corporation should attach primary importance to harmonizing planning and development at the Incheon FEZ to minimize overall delivery time, to secure sufficient land space to perform complex logistics, and to enhance accessibility. Furthermore, the fact that global firms are searching for a location where airport and seaport services can be simultaneously provided in one place clearly indicates that the New Incheon Port should be developed in time for the Incheon FEZ to maximize its potential.

Last, but not least, for Korea to become the major business and logistics hub in Northeast Asia would feed Korea's economy in the future. So, in the next phase of moving Korea's per capita income to US\$20,000, Korea needs not just incremental improvements or extra efforts, but needs major and fundamental changes in both mindsets and strategies.

\section{REFERENCES}

Brush, T.H., Maritan, C.A. and Karnani, A. (1999) "The Plant Location Decision in Multinational Manufacturing Firms: An Empirical Analysis of International Business and Manufacturing Strategy Perspectives," Production and Operations Management, vol. 8, No. 2, Summer 1999, pp. 109-131.

Button, Kenneth and Stough, Roger (1998) The Benefit of Being a Hub Airport City: Convenient Travel and High-Tech Job Growth, The Institute of Public Policy, George Mason Univ., Nov.

Erie, Steven P., Kasarda, John D., McKenzie, Andrew M., and Molley, Michael A. (1999) A New Orange County Airport at El Toro: Catalyst for High-Wage, High Tech Economic Development, The Orange County Business Council, Dec.

Harding, Alan (1994) “Amsterdam and Rotterdam," in Alan Harding et al. (eds.), European cities toward 2000, Manchester Univ. Press.

Hayes, John (2002) "Global Trends of Logistics Services in Port Areas," paper presented at the Regional Seminar on Commercial Development of Ports as Logistics Centers, Bangkok, Thailand, July 11-12.

International Institute for Management Development (IMD) (2001) The World Competitiveness Yearbook 2000.

Jagersma Research \& Consultancy (1994) De Distributiehypothese gevalideerd. Juhel, Marc H. (1999) "The Role of Logistics in Stimulating Economic Development," paper presented at the China Logistics Seminar, Beijing, China, November 28-29.

Jun, Il-Soo (2002) Commercial Developments of Regional Ports as Logistics Centers, ST/ESCAP/2194, Bangkok: UN ESCAP. (2001) A New Paradigm for a National Development Strategy: Building a Logistics Center in Northeast Asia, Korea Transport Institute.

Kasarda, John D. (1998) "Time-Based Competition and Industrial Location in the Fast Century," Real Estate Issues, Winter, pp. 24-29.

Kim, Joon-Dong (1997) Barriers and Facilitation Measures in Inducing Foreign Direct Investment (in Korean), Korea Institute of International Economic Policy. 
Korea Research Institute for Human Settlement (KRIHS) (2000) A Study on the Provision of Industrial Sites for Effective Inducement of Foreign Investment (in Korean).

Ministry of Finance and Economy (MOFE) and Incheon Metropolitan City (2003) Recent Developments and Prospects: Free Economic Zone.

Nasser, Haya El (2003) "Make Way for the 'Aerotropolis'," http://www.usatoday.com.

O' Brien, Phil (2001) "The Role of Distribution and Logistics Centers on the New Global AutoRoute," paper presented at the $22^{\text {nd }}$ World Ports Conference of the IAPH, Montreal, May 19-26.

Porter, Michael E. (1990) The Competitive Advantage of Nation, The Free Press.

Radstak, Bin G. and Ketelaar, M.H. (1999) Worldwide Logistics, HIDC.

UNCTAD $(1998,1999)$ World Investment Report, United Nation. 